\title{
New role model for teachers in Higher Education?
}

\author{
Hagen HOCHRINNER \\ FH Joanneum, Graz, Austria \\ hagen.hochrinner@fh-joanneum.at
}

\begin{abstract}
The traditional university was for decades not called into question as a place for $R \& D$ and higher education.

At the one hand this enabled successful independent research, at the other hand there was few need to reflect traditional structures of knowledge transfer.

The nowadays omnipresent decrease in financial resources has caused universities to compete for financial support from the business sector; additionally universities have to justify their existence for their duties in education for providing the society with academic skilled working forces. This leads to a competition between the universities and to attract applicants they have to boost the attractivity of the offered study programs. Education became a market.

The traditional methods of ex-cathedra teaching have been the standard mean of knowledge transfer for a long time. The pedagogical concepts at the tertiary level were neglected; in many institutions the teaching duties were seen more as a burden than mission.

The paper will show that the values of our great philosophers are still valid and how the new teaching approach of Dual Education can fulfill requirements of industry for young academics at the entrance to business life.

The development of dual study programs and a new pedagogical approach in teaching methods may be one mean to face the challenges for the successful education especially in the technical sciences.
\end{abstract}

Keywords: teaching, dual study program, cooperative education, knowledge transfer

\section{INTRODUCTION}

The presented exposition will deal and highlight the following questions: What does the economy/industry expect from students after graduation? What does business expect from universities and schools?

What do great philosophers say about educational goals?

What does it mean for the role model of a cooperative teacher? What is a teacher? What is the teacher's role and what are his/her traditional duties and expectations?

How can the teaching model of Dual Education be supportive in the learning processes?

\section{EXPOSITION}

The Dual Study program of "Production, Technology and Organization" at the University of Applied Sciences FH Joanneum in Graz was the first dual study program in Austria. This so called Dual Education roots in the traditional secondary education of apprenticeship as it is known in the German speaking countries (Austria, Germany and Switzerland).

"Dual Education", in the English speaking world called "Cooperative Education", transfers the idea of having two learning environments (university and company) in the tertiary level - academic - 
education.

The requirements of industry concerning the education of academic employees are rising, but it is not only the subject related specific educational content which has to be improved more over there are values of the Humboldt's ideal of "studium generale" and personal developement which become more and more requested.

The working environment is changing rapidly and the buzz-phrase "industrial internet of things" (in German speaking countries called: "Industry 4.0") has become omnipresent in all production branches. There is no question about the fact that our society needs reseachers and scientists; nevertheless, because of the industrial internet, there is a rising demand in industry for highly qualified academics even besides R\&D.

The German Chamber of Industry and Trade showed already in their survey in 2014 what the main expectations of business are concerning graduates from bachelor programs (see Fig. 1).

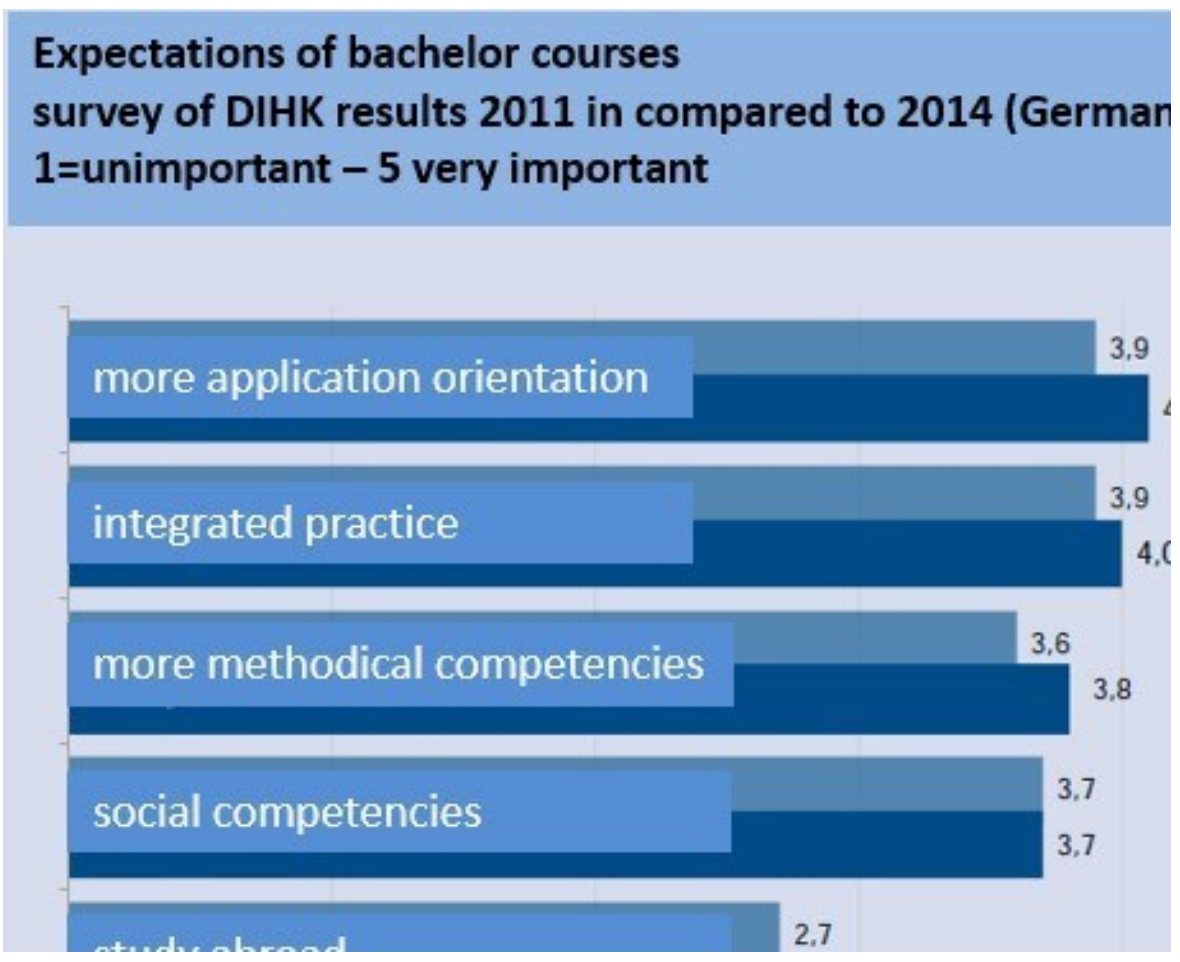

Figure 1: "Expectations of bachelor programs" (Heikaus and Flasdick, 2015)

Fig. 1 shows clearly that the needs of business in Germany do not lie squarely in specific scientific knowledge. Most companies need well-educated engineers who are employable in the field of application.

Most students at traditional universities have maximum one semester internship experience. Often it is the case that the internship does not support the content of the study program. Social competencies should also be developed. Mostly, students are educated as "lone warriors" as they get used to being in permanent competition with their colleagues.

Fig. 2 und Fig. 3 show that competency in R\&D is really not the main target and demand. Competency in R\&D is expected anyway but there are also softskills which are vital. 


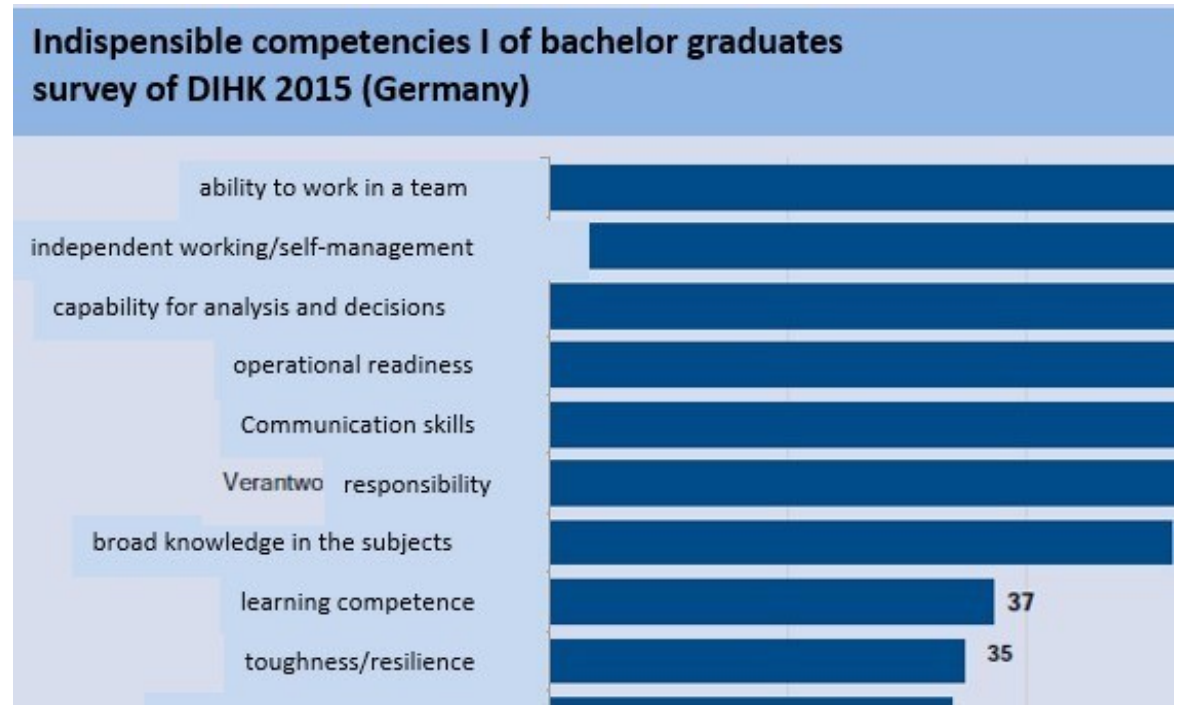

Figure 2: “Indispensible competencies I" (Heikaus and Flasdick, 2015)

A look at the Fig. 2 and Fig. 3 show the "Indispensible compentencies" which are expected by German industry to be the educational result of a bachelor graduate. It is quite interesting that the top 11 expectations are more or less in accordance with the great European philosophers and their ideals.

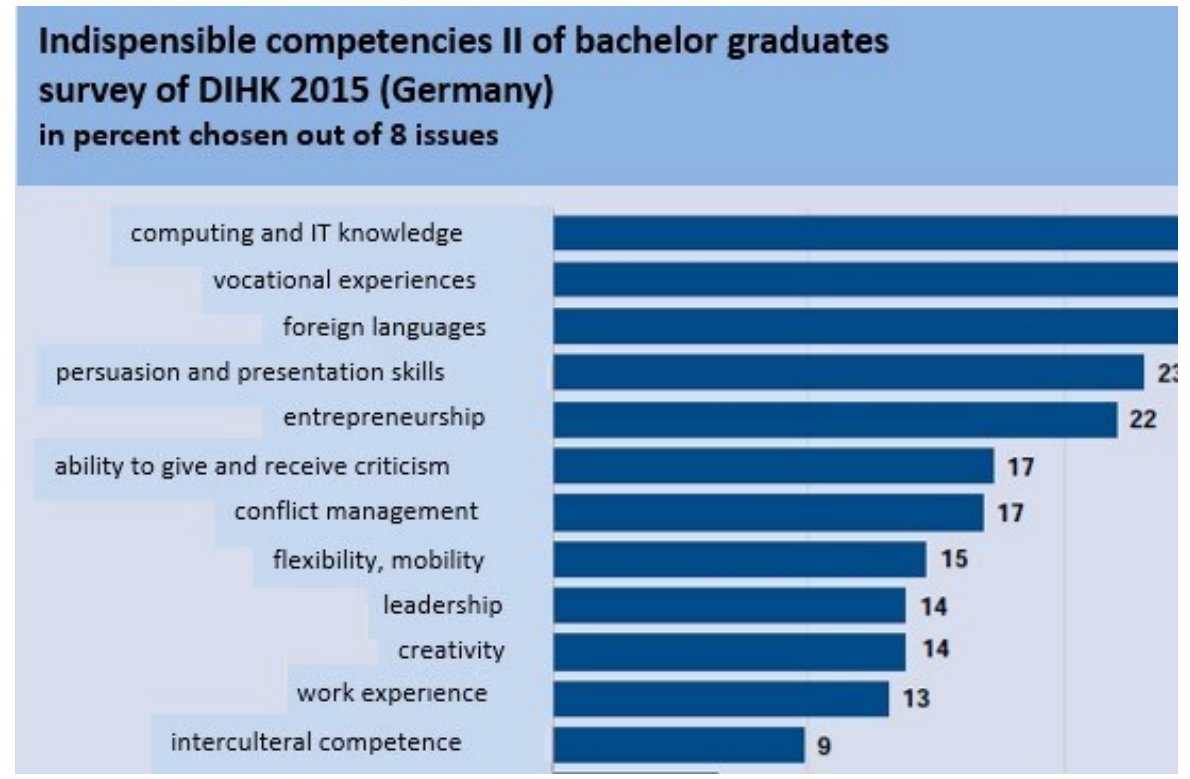

Figure 3: "Indispensible competencies II" (Heikaus and Flasdick, 2015)

For example autonomous individual, according to Alexander v. Humboldt, is said to be an individual who gains self-determination (autonomy) and maturity through his use of reason. To quote Humboldt: "To transform as much world as possible into one's own person is life, in the 
higher sense of the word".

"The endeavor is to work to the fullest extent possible in/at the world and thereby develop as a subject.

To become a world citizen is to deal with the great questions of humanity: to look for peace, justice, exchange of cultures, other gender relations or a different relationship with nature to strive"(Hofmann, 2010).

Immanuel Kant describes the concept of maturity as the inner and outer faculties of selfdetermination and self-responsibility.

He describes maturity is as state of independence. It says that you can speak and care for yourself. "Maturity is often associated with the concept of emancipation" (Berlinische Monatsschrift, 1784).

Furthermore in his famous text, in answer to the question "What is Enlightenment?" Kant wrote in 1784: "Enlightenment is the outcome of man's self-imposed immaturity.

Immaturity is the inability to use one's mind without the guidance of another. This self- immaturity is self-inflicted if its cause is not due to lack of understanding but to resolution and courage to use it without the guidance of another. 'Sapere aude! Have the courage to use your own understanding!' This is the motto of the Enlightenment" (Berlinische Monatsschrift, 1784).

While the educational understanding of the last decades is usually based on a person's ability to be conditioned and therefore presupposes the "meaning" or has to presuppose unreflectively, new education leads to move independently on the level of the senses and to gain the starting point for everything else.

Originality replaces tradition.

In addition to the knowledge, in the future, this will be a self-reliant orientation knowledge, which in turn determine one's knowledge and competencies. Traditionally, "learning" meant to pick up certain ideas or methods. In the future, it will be more a matter of developing knowledge and the ability to autonomously organize the processes of knowledge acquisition. Informal learning is increasingly replacing learning that can be organized in institutions (Dietz, 2013).

The short excursion to the thoughts and ideals of the great European philosophers that just took place shows that aims of education have not changed during the last 300 years.

Our pupils and students still need

- Maturity

- Resolution

- Courage

\section{- Self-determination}

- Self-responsibility

ans businesses of the Western World expect alumnies/graduates with these traits.

The role of the teacher is to fullfill the demands of education and of business in cooperation with enterprises. This means that students should have the chance to apply the theoretical knowledge at internships after each semester at university.

"A teacher is a person who, through higher competence in certain areas, teaches something to others. Since it is not a protected term, everyone can basically refer to a phase of the imparting of knowledge, skills, lifestyles or education" (Pfeifer, 1993).

This definition shows that everybody can be a teacher. The new way of teaching makes professors and teachers to "knowledge-facilitators" and "knowledge-coaches". On the one hand, they have to impart traditional values according to great philosophers; on the other hand, they have to orientate the teaching content to meet demands of the industry.

The aim and method in teaching must be not ex-cathedra teaching but to motivate and escort students in a cooperative way together with industry.

Both teachers, student's mentors in industry and the student himself take responsibilty for the career and sucess of the student.

There are good experiences with dual education especially in technical study programs. There is a good balance of theory and practice with the added value of accessing the knowledge of the degree program. 
According to the Austrian definition of Dual Education there are two learning environments for the student - the university for the theoretical background and the company for applying the theoretical knowledge in practice.

At University fundaments of the subjects are taught in a (peer-)coaching process. The student is given a certain input and has further to elaborate the teaching material. The Professor is assisting in the process nevertheless the student takes responsibility for his success.

In the company the project works for the students are in accordance with the curriculum. The company challenges the students in projects to show that he is well-educated concerning the theoretical background and also able to apply his knowledge practically. The student is integrated in the working process and also has to show (or develop) the softskills and responsibilities which he will need as a full employee after graduation.

Due to this combination there is much more sustainability in the process of learning as the student is able to recognize the meaning- and usefullness of the subjects.

With the graduation of the student practically a full-fledged employee who requires no further training is available for the industry.

The curriculum is constantly adapted and by this at the state of the art and needs of industry.

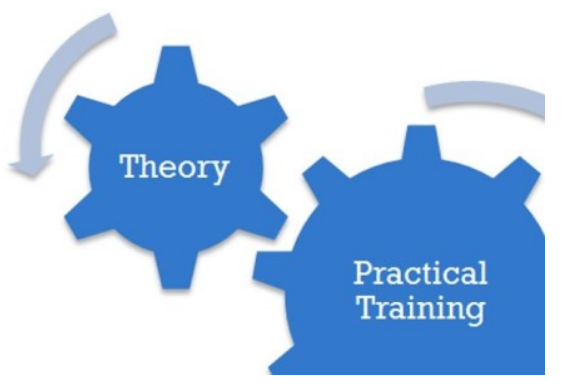

Figure 4: “Theory and practical training" (Mahler, 2015)

\section{CONCLUSION}

The traditional values which are introduced by the old philosophers are more up to date than ever. The new demands for Universities are not only to teach theoretical knowledge to the students but to teach them personal values which are nowadays called "softskills". The so called Dual or Cooperative Education in higher education is the new approach in fulfilling the demands of industry.

The system of Dual Education not only rises the value of the alumnies on the labour market it also offers professors/teachers the chance to be in touch with real life and permanently increase their expertise and knowlegde.

Dual education develops a new role for the professor/teacher as "science-manager" by using the state-ofthe-art teaching according to the industry's demands.

The role of the teachers changes from a frontal ex-cathedra teacher to a coach.

The means mentioned above will also raise the reputation and competiveness of universities implementing these practices.

\section{REFERENCES}

Hofmann Jürgen, Welche Bedeutung hat das Humboldt'sche Erbe für unsere Zeit? 225. Humboldt Gesellschaft, 2010

Berlinische Monatsschrift, 1784 Beantwortung der Frage: Was ist Aufklärung?, S. 481-494 Dietz Karl-Martin, RoSE - Research on Steiner Education Vol.4 No.2, 2013. 
Heikaus Dr. Oliver, Flasdick Julia, Online Umfrage Mai 2015, DIHK | Deutscher Industrie- und Handelskammertag e.V., Berlin Brüssel

Mahler Evgenia, Hochschule Wismar, Project EUDURE European dual research and education, 01DS15017,2015

Pfeifer Wolfgang, Etymologisches Wörterbuch des Deutschen, 2.Auflage, DTV, München 1993. 